\title{
ATP-Binding Cassette Sub-Family B Member 5
}

National Cancer Institute

\section{Source}

National Cancer Institute. ATP-Binding Cassette Sub-Family B Member 5. NCI Thesaurus. Code C73557.

AT P-binding cassette sub-family B member 5 (812 aa, $20 \mathrm{kDa}$ ) is encoded by the human ABCB5 gene. This protein plays a role in small molecule membrane transport and drug resistance in some melanomas. 